\title{
On the possible increasing of efficiency of ship power plant with the system combined of marine Diesel engine, gas turbine and steam turbine in case of main engine cooperation with the gas turbine fed in series and the steam turbine
}

\author{
Marek Dzida, Assoc. Prof. \\ Jerzy Girtler, Prof. \\ Gdansk University of Technology \\ Sebastian Dzida, M. Sc. \\ Petrobaltic S.A.
}

\begin{abstract}
The article presents a concept of a combined large power ship propulsion system consisting of the leading Diesel main engine, associated with a power gas turbine and the steam turbine system which utilise the energy contained in the exhaust gas leaving the Diesel engine. In the examined variant of the combined system the power turbine is fed in series with the exhaust gas. A calculation algorithm is given along with the results of calculations of particular subsystems of: the turbocharging system, the power gas turbine, and the steam turbine cycle. Assumptions and limits adopted in the calculations are presented. Selected system parameters were confronted with the results of experimental investigations available in the literature. The power optimisation of the entire combined ship power plant was only performed taking into account the thermodynamic point of view, leaving aside technical and economic aspects. Numerical calculations were performed for the $52 \mathrm{MW}$ low-speed Diesel engine produced by Wärtsilä.
\end{abstract}

Keywords: Ship power plants; combined systems; Diesel engine; gas turbine; steam turbine

\section{INTRODUCTION}

The low-speed main engine used for driving a ship has the highest efficiency of all heat engines. What is more, it burns the cheapest residual fuel. However, there are some problems with keeping the emission of harmful substances by this engine to the atmosphere at a permissible level.

The article analyses a variant in which the turbocharger and the power turbine are connected in series. An option was also taken into account in which the exhaust gas was utilised in the waste heat boiler working for the steam turbine.

The analysed combined power plant consists of a Diesel engine 9RTA-96C, identical to that discussed in $[2,3]$, the power turbine, fed in series, and the steam system with a steam turbine. Additional power of the propulsion system, obtained both from the power turbine and the steam turbine, is transmitted to the ship propeller shaft via a mechanical gear. Behind the turbocharger, a power gas turbine is installed in series, from which the exhaust gas flows through the waste heat boiler producing the steam to drive the steam turbine. Steam consumption for ship's own needs was taken into account in the calculations.

For the assumed efficiency of the turbocharger and the power turbine, the power of the gas turbine was calculated, while the steam turbine cycle was optimised with respect to the maximum power of the adopted two-pressure waste-heat boiler. The optimisation of the steam turbine system took into account limits resulting from practical solutions used in power transmission systems.

\section{CONCEPT OF A COMBINED SYSTEM} - SERIES FEEDING OF POWER TURBINE

The combined cycle includes an additional power turbine and a waste heat boiler which produces the steam for ship's own needs and for an additional steam turbine. The use of the power gas turbine is possible due to high efficiency of the turbochargers, which makes it possible to increase the pressure of the gas behind the turbocharger turbine. This pressure is higher than the pressure of the exhaust gas in front of the waste heat boiler, which results from pressure losses connected with the flow of the exhaust gases through the boiler. The pressure difference between these two pressures provides opportunities for the use of an additional gas turbine, bearing the name of the power turbine, in the system.

This solution leads to the increase of power of the entire power transmission system, as the volume of fuel delivered to the Diesel engine does not change, while both the power turbine and the steam turbine deliver additional power.

It results from operating low-load tests of conventional power transmission systems with Diesel engines with turbocharging that the amount of the exhaust gas in the 


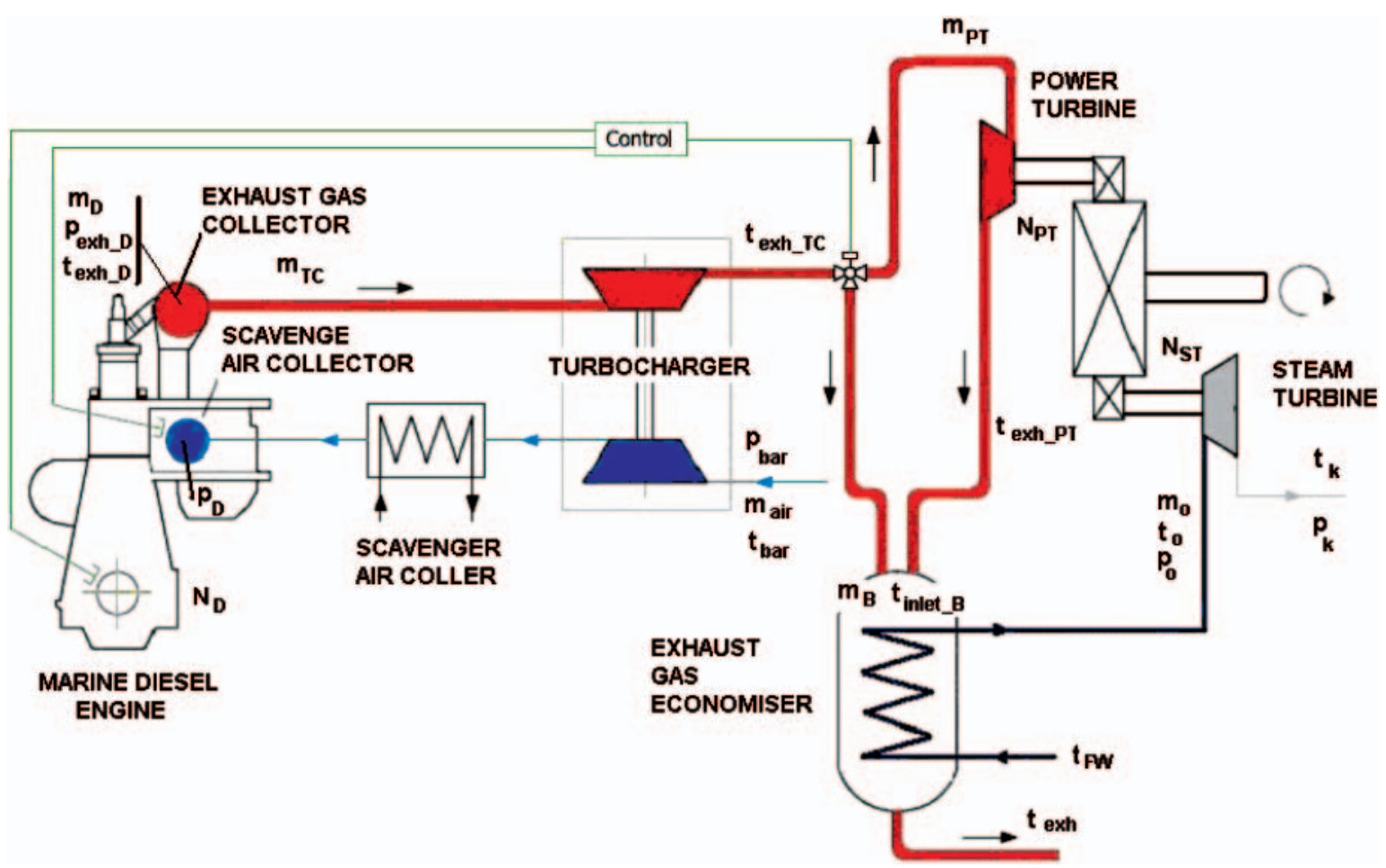

Fig. 1. Combined ship power transmission system

turbocharger is not sufficient to secure stable engine operation. In that case additional air blowers, situated at engine inlet, are started. That is why the proposed combined power transmission system should have power turbine bypass pipes (Fig. 1) which direct the exhaust gas from the turbocharger to the waste heat boiler during low-load intervals. This system will be controlled automatically by a valve for which the control signal will be the pressure of the turbocharging air, the engine torque, or the angular speed of the propeller shaft. This control system also seems to provide opportunities for the operation of the ship power transmission system without the power turbine. A possibility to switch off the power turbine results in the increase of the turbocharger's power output, which further leads to the increase of both the turbocharging pressure and the volume of the turbocharging air, all this increasing the ability to manoeuvre the engine, in particular fast reaching the maximum power at important moments of power transmission system operation points. Also in cases of large power of the main (piston) engine, increasing the power of the power turbine may lead to the decrease of the power of the turbocharger, thus increasing the power of the entire power transmission system.

\section{OPERATING PARAMETERS OF THE MAIN ENGINE TURBOCHARGER}

The engine 9RTA-96C has constant-pressure turbocharging [5]. Three PCL-type turbochargers were produced by ABB. From the exhaust gas collector the exhaust gas, having the temperature $t_{\text {exh } D}$ and the pressure $\mathrm{p}_{\text {exh } D}$ flows directly to the turbochargers. In the catalogue the producer [5] does not present all parameters concerning turbocharging. In further calculations the temperature $t_{\text {exh } D}$ and the pressure $\mathrm{p}_{\text {exh D }}$ of the exhaust gas in the exhaust collector were assumed based on the analysis reported in [2].

It was assumed in turbocharging calculations for the combined system that the power needed for driving turbocharger turbines is sufficiently large if the pressure behind the turbocharger turbine is higher than the inlet pressure of the exhaust gas in the waste heat boiler.
The pressure of the exhaust gas behind the turbocharger is calculated from its power balance:

$$
\pi_{\mathrm{T}}=\left[\frac{1}{1-\frac{1}{\eta_{\mathrm{TC}}} \cdot \frac{\mathrm{m}_{\mathrm{air}}}{\mathrm{m}_{\mathrm{TC}}} \cdot \frac{\mathrm{c}_{\mathrm{a}}}{\mathrm{c}_{\mathrm{g}}} \cdot \frac{\mathrm{t}_{\mathrm{bar}}}{\mathrm{t}_{\text {inlet_TC }}} \cdot\left(\pi_{\mathrm{C}}^{\frac{\kappa_{\mathrm{s}}-1}{\kappa_{\mathrm{s}}}}\right)}\right]^{\frac{\kappa_{\mathrm{g}}}{\kappa_{\mathrm{g}}-1}}
$$

where:

$\pi_{\mathrm{C}}=\mathrm{p}_{\text {exh } \mathrm{C}} / \mathrm{p}_{\mathrm{bar}} \quad$ is the compression ratio in the turbocharger $\pi_{\mathrm{T}}=\mathrm{p}_{\text {exh_TC }} / \mathrm{p}_{\text {exh_D }}$ is the expansion ratio in the turbocharger turbine.

The efficiency of the turbocharger was defined as:

$$
\eta_{\mathrm{TC}}=\eta_{\mathrm{C}} \cdot \eta_{\mathrm{T}} \cdot \eta_{\mathrm{m}}
$$

The compressor efficiencies $\eta_{\mathrm{C}}$ and $\eta_{\mathrm{T}}$ in the above formula were determined in the following way: the compressor efficiency was calculated from the line of cooperation of the engine RTA-96C with the ABB compressor. Changes of turbocharger turbine efficiency were calculated from MAN $B \& W$ experimental tests [4]. It was assumed that the efficiency of the ABB turbine changes in the similar way. This relation made the basis for determining the efficiency of the ABB turbocharger turbine cooperating with the engine 9RTA-96C as a function of its load. The results are shown in Fig. 2.

The temperature of the exhaust gas leaving the turbocharger turbine was calculated from the transformed formula which defines the turbine efficiency as:

$\mathrm{t}_{\mathrm{exh} \_\mathrm{TC}}=\left(\mathrm{t}_{\mathrm{exh} \_\mathrm{D}}+273.15\right) \cdot\left[1-\eta_{\mathrm{T}}\left(1-\frac{1}{\pi_{\mathrm{TC}} \frac{\kappa_{\mathrm{g}}-1}{\mathrm{~kg}}}\right)\right]-273.15$ 

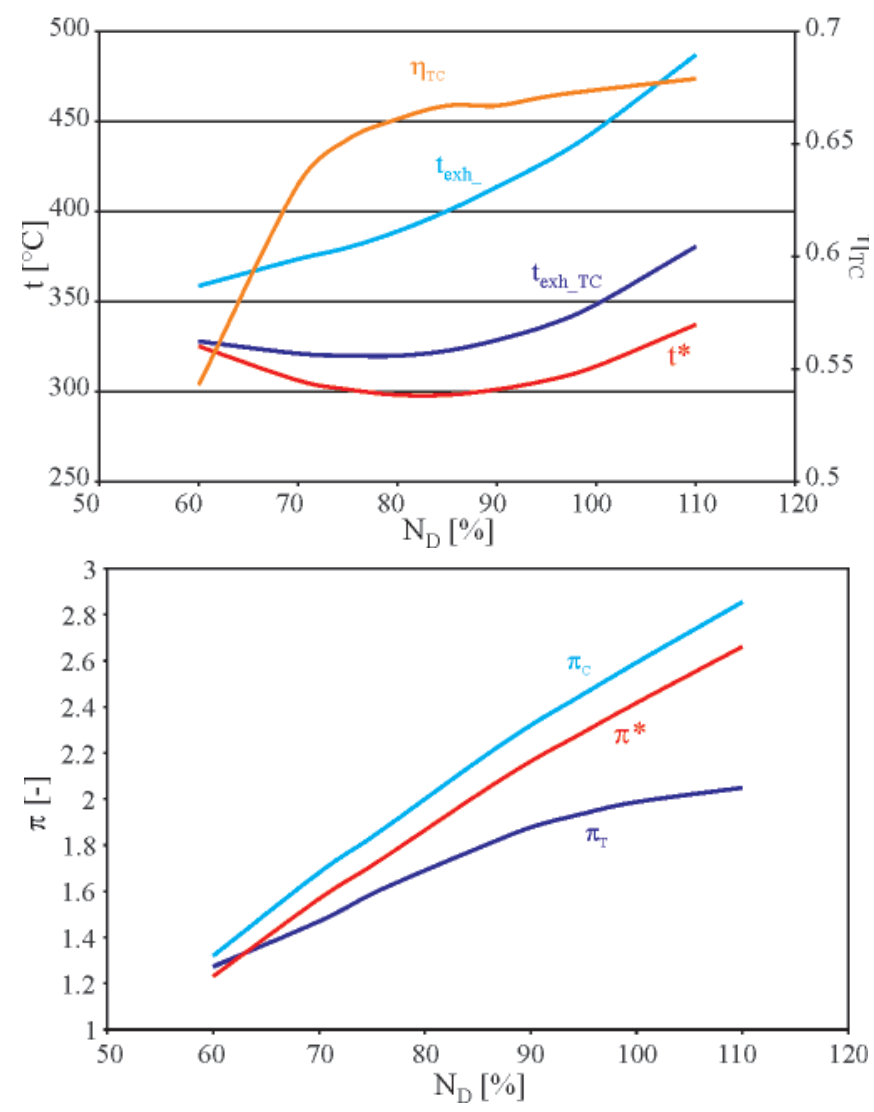

Fig. 2. Characteristics of turbocharger parameters as function of main engine load: $\boldsymbol{t}^{*}$ - turbocharger outlet temperature in a standard engine (producer's data), $\pi^{*}$ - expansion rate in the turbocharger turbine (producer's data)

It results from the performed calculations that when the load is larger than $65 \%$, the operation of the power turbine in the system is possible, Fig. 2. For the presently used turbochargers the turbocharger turbine power is reached at low compression. The excess pressure of the exhaust gas can be expanded in the additional power turbine.

\section{POWER TURBINE CALCULATIONS}

In the adopted concept of the combined power transmission system, Fig. 1, the power turbine is situated behind the turbocharger. The exhaust gas from the turbocharger flows to the power turbine. The entire mass flow rate of the exhaust gas leaving the main engine expands in the power turbine, thus delivering extra power to the ship power transmission system.

The pressure behind the power turbine depends on the losses taking place during the flow through the waste heat boiler and outlet silencers. Following common practice, it was assumed in further calculations that the pressure behind the power turbine is by $3 \%$ higher than the barometric pressure, i.e.

$$
\mathrm{p}_{\text {exh PT }}=1.03 \mathrm{p}_{\text {bar }}
$$

The expansion ratio in the power turbine can be calculated as:

$$
\pi_{\mathrm{PT}}=\frac{\mathrm{p}_{\text {inlet_PT }}}{p_{\text {exh PT }}}
$$

The power of the power turbine was calculated from the following formula

$$
\mathrm{N}_{\mathrm{PT}}=\eta_{\mathrm{PT}} \cdot \mathrm{m}_{\mathrm{PT}} \cdot \mathrm{c}_{\mathrm{g}} \cdot \mathrm{t}_{\text {inlet_PT }} \cdot\left(1-\frac{1}{\left(\pi_{\mathrm{PT}}\right)^{\frac{\mathrm{kg}_{\mathrm{g}}-1}{\kappa_{\mathrm{g}}}}}\right)
$$

It was assumed in the calculations that the power turbine efficiency $\eta_{\mathrm{PT}}$, depends on the expansion ratio, according to the data presented by MAN B\&W for the turbocharger turbine [1]. This assumption can be considered correct, as the producers make use of gas turbines installed in turbochargers as power turbines.

The temperature of the exhaust gas leaving the power turbine was calculated from the following relation:

$$
\mathrm{t}_{\text {exh_PC }}=\left(\mathrm{t}_{\text {inlet_PT }}+273.15\right) \cdot\left[1-\eta_{\mathrm{PT}}\left(1-\frac{1}{\pi_{\mathrm{PT}} \frac{\frac{\kappa_{\mathrm{g}}-1}{\kappa_{\mathrm{g}}}}{2}}\right)\right]-273.15
$$

The power turbine parameters were calculated using a computer programme (the source code is included as Appendix) taking into account the above assumptions. Fig. 3 presents the calculated values of the selected power turbine parameters as a function of the internal combustion engine load.

The use of the power turbine in the system resulted in power increase of the entire system from 3 to $9 \%$, compared to the standard engine power. The power of the power turbine increases with the increase of power of the internal combustion engine. It results from the performed calculations that when the load is smaller than $65 \%$ of the internal combustion engine power, the power turbine cannot be used as its power nears zero. In this case the power turbine is to be disconnected from the system. This conclusion is in accordance with the results of turbocharging process calculations.

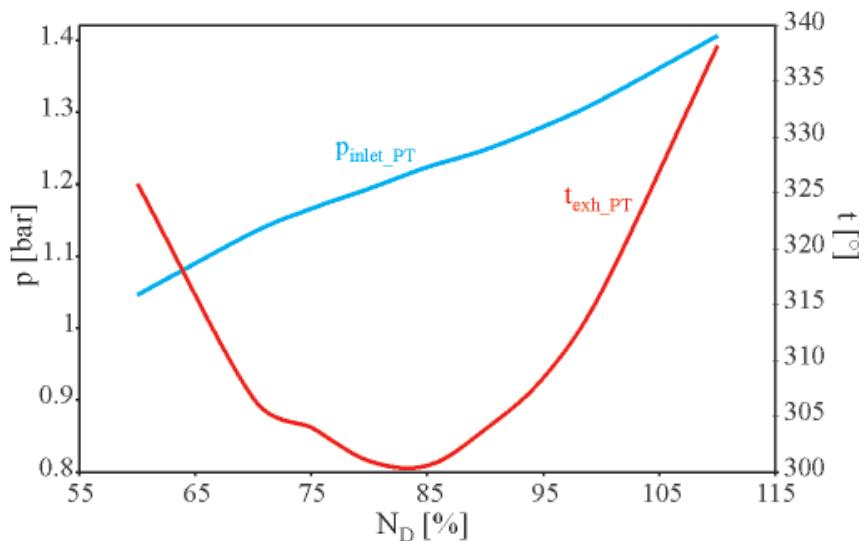

Fig. 3. Selected power turbine parameters vs. main engine load

\section{STEAM CYCLE OPTIMISATION CALCULATIONS}

In the analysed combined power transmission system, Fig. 1, the exhaust gas leaving the power turbine is directed to the waste heat boiler, where it produces steam used to meet ship's own needs and supply the steam turbine. The steam turbine transmits the power, via a gear, to the propeller shaft. The system of the steam turbine cycle was adopted following the description given in [2]. In the steam system a two-pressure waste heat boiler was used. The calculations were preformed using the computer programme [2] to search the maximum power of the steam turbine. The steam cycle was optimised for two main engine loads, i.e. for the power corresponding to $100 \%$ and $90 \%$ of the thermal load of the piston engine.

Table 1 collects the results of calculations for two internal combustion engine load regimes which corresponded to the maximum available power of the steam turbine. It results from the analysis of the steam cycle calculations performed for the examined combined power transmission system that the maximum available power of the steam turbine equals 7.25 
or $7.96 \%$ of the internal combustion engine load, depending on the load.

In practical application, the steam turbine system needs some limits to be placed on its parameters as a result of the adopted designing, constructional and operating assumptions. For the adopted limits [2] the steam power transmission system was optimised for the second time to find a solution for which the power of the steam turbine reaches its maximum. Tab. 1 presents the parameters of this system, obtained taking into account the adopted limits. Due to the limits in the steam turbine cycle we cannot utilise the entire power resulting form the calculations performed for the cycle without limits. The presented analysis of the steam cycle reveals that the additional use of the steam turbine in the combined system increases the power output of the system by about $6.5 \div 7.8 \%$ and decreases the fuel consumption.

\section{THERMODYNAMIC ANALYSIS OF THE COMBINED POWER TRANSMISSION SYSTEM}

The application of the combined system in a classical ship power transmission system with a low-speed Diesel engine leads to the increase of power and to the decrease of the specific fuel consumption. Tab. 2 collects the results of calculations of particular components of the combined system. It results from the performed analysis that the sole use of a power turbine increases the power output of the system by $5.5 \div 7 \%$, depending on the Diesel engine load. At the same time the steam system alone (without the power turbine) increases the power output of the plant by $6.5 \div 7.5 \%$. In the complete combined system composed of the piston engine as a leading engine, the power turbine, and the steam turbine, the power output of the system increases by $12 \div 15 \%$. This power output increase is not generated by extra fuel delivered to the system but is connected with deep utilisation of the exhaust gas leaving the piston engine. This system also makes it possible to reduce the specific fuel consumption by $11 \div 13 \%$ compared to the traditional power plant with an internal combustion engine.

\section{COMPARING VARIANTS OF SHIP POWER TRANSMISSION SYSTEMS}

Tabs 3, 4 and 5 show selected parameters of the calculated combined systems, which were taken from the above presented variants of the combined ship power transmission system composed of the main engine, and the power and steam turbine systems.

In the steam turbine cycle of the combined system, the cycle parameters differ little between each other in the analysed variants. The live steam temperature differs by $3^{\circ} \mathrm{C}$ in one case, while the live steam pressure also does not differ much. The pressure in the first stage of the boiler and in the degasifier, as well as the temperature of the exhaust gas leaving the power transmission system are the same for all variants, Tab. 3. The largest power output of the steam turbine cycle is reached in the combined system variant with the steam turbine and power turbine fed in series with the exhaust gas, Tab. 4. Differences in steam turbine power output for particular variants for $90 \%$ of the main Diesel engine load are approximately equal to $4 \%$.

Tab. 1. Optimum steam cycle parameters in a combined cycle consisting of Diesel engine-power turbine (series feeding) - steam turbine

\begin{tabular}{|c|c|c|c|c|c|c|c|c|c|c|c|c|c|c|}
\hline No & $\begin{array}{c}\mathrm{N}_{\mathrm{D}} \\
{[\%]}\end{array}$ & $\begin{array}{c}\mathbf{t}_{\mathbf{o}} \\
{\left[{ }^{\circ} \mathrm{C}\right]}\end{array}$ & $\begin{array}{c}\mathbf{p}_{\mathbf{o}} \\
{[\text { bar] }}\end{array}$ & $\begin{array}{c}\mathbf{p}_{\mathbf{I}} \\
\text { [bar] }\end{array}$ & $\begin{array}{c}\mathbf{t}_{\mathrm{I}} \\
{\left[{ }^{\circ} \mathrm{C}\right]}\end{array}$ & $\begin{array}{c}\mathbf{p}_{\mathbf{g}} \\
{[\mathbf{b a r}]}\end{array}$ & $\begin{array}{c}\mathbf{t}_{\text {exh }} \\
{\left[{ }^{\circ} \mathrm{C}\right]}\end{array}$ & $\begin{array}{c}\mathbf{t}_{\mathrm{FW}} \\
{\left[{ }^{\circ} \mathbf{C}\right]}\end{array}$ & $\mathbf{X}$ & $\begin{array}{c}\mathbf{m}_{\mathbf{o}} \\
{[\mathbf{t} / \mathbf{h}]}\end{array}$ & $\begin{array}{c}\mathbf{m}_{\mathrm{I}} \\
{[\mathbf{t} / \mathbf{h}]}\end{array}$ & $\begin{array}{c}\mathbf{m}_{\mathrm{u}} \\
{[\mathrm{t} / \mathbf{h}]}\end{array}$ & $\begin{array}{c}\mathbf{N}_{\mathrm{ST}} \\
{[\mathbf{k W}]}\end{array}$ & $\mathbf{N}_{\mathrm{ST}_{\mathrm{T}}} / \mathbf{N}_{\mathrm{D}}$ \\
\hline \multicolumn{15}{|c|}{ without limits } \\
\hline 1 & 100 & 301 & 25.0 & 7.0 & 165 & 0.50 & 154 & 82 & 0.8753 & 15.02 & 11.17 & 1.93 & 4097 & 0.0796 \\
\hline 2 & 90 & 286 & 23.0 & 7.0 & 165 & 0.50 & 153 & 82 & 0.8742 & 12.52 & 9.66 & 1.79 & 3361 & 0.0725 \\
\hline \multicolumn{15}{|c|}{ with limits } \\
\hline 1 & 100 & 301 & 23.0 & 7.0 & 165 & 2.00 & 162 & 121 & 0.8786 & 15.79 & 10.78 & 3.85 & 3880 & 0.0754 \\
\hline 2 & 90 & 286 & 23.0 & 7.0 & 165 & 2.00 & 164 & 121 & 0.8742 & 12.52 & 10.01 & 3.22 & 3193 & 0.0689 \\
\hline
\end{tabular}

Tab. 2. Power output, efficiency and specific fuel consumption of the combined ship power transmission system with the two-stroke engine 9RTA 96C, power turbine (fed in series) and steam turbine

\begin{tabular}{|c|c|c|c|c|c|c|c|c|}
\hline $\begin{array}{l}\mathrm{N}_{\mathrm{D}} \\
{[\%]}\end{array}$ & $\begin{array}{c}\mathbf{N}_{\mathrm{D}} \\
{[\mathbf{k W}]}\end{array}$ & $\begin{array}{l}\mathbf{N}_{\mathrm{PT}} \\
{[\mathbf{k W}]}\end{array}$ & $\begin{array}{c}\mathbf{N}_{\mathrm{PT}} / \mathbf{N}_{\mathrm{D}} \\
{[\% \mathbf{\%}]}\end{array}$ & $\begin{array}{c}\mathbf{N}_{\mathrm{ST}} \\
{[\mathbf{k W}]}\end{array}$ & $\begin{array}{c}\mathbf{N}_{\mathrm{ST}} / \mathbf{N}_{\mathrm{D}} \\
{[\%]}\end{array}$ & $\begin{array}{c}\mathbf{N}_{\mathrm{PT}}+\mathbf{N}_{\mathrm{ST}} \\
{[\mathrm{kW}]}\end{array}$ & $\underset{[\%]}{\mathbf{N}_{\text {combi }}} \mathbf{N}_{\mathrm{D}}$ & $\begin{array}{l}\mathbf{N}_{\text {combi }} \\
{[\mathrm{kW}]}\end{array}$ \\
\hline 100 & 51480 & 3643 & 7.08 & 3880 & 7.54 & 7523 & 14.61 & 59003 \\
\hline 90 & 46332 & 2572 & 5.55 & 3193 & 6.89 & 5765 & 12.44 & 52097 \\
\hline $\begin{array}{l}\mathrm{N}_{\mathrm{D}} \\
{[\%]}\end{array}$ & $\begin{array}{c}\mathbf{N}_{\mathrm{D}} \\
{[\mathrm{kW}]}\end{array}$ & $\begin{array}{c}\mathbf{b}_{\text {ed }} \\
{[\mathbf{g} / \mathbf{k W h}]}\end{array}$ & $\begin{array}{c}\mathbf{b}_{\mathrm{ePT}} \\
{[\mathbf{g} / \mathbf{k W h}]}\end{array}$ & $\begin{array}{c}\Delta \mathbf{b}_{\mathrm{ePT}} / \mathbf{b}_{\mathrm{eD}} \\
{[\%]}\end{array}$ & $\begin{array}{c}\mathbf{b}_{\text {est }} \\
{[\mathrm{g} / \mathbf{k W h}]}\end{array}$ & $\begin{array}{c}\Delta \mathbf{b}_{\mathrm{eST}} / \mathbf{b}_{\mathrm{eD}} \\
{[\% \mathbf{0}]}\end{array}$ & $\begin{array}{c}\mathbf{b}_{\text {ecombi }} \\
{[\mathbf{g} / \mathbf{k W h}]}\end{array}$ & $\begin{array}{c}\Delta \mathbf{b}_{\text {ecombi }} / \mathbf{b}_{\mathrm{eb}} \\
{[\% \mathbf{0}]}\end{array}$ \\
\hline 100 & 51480 & 174 & 162.5 & -6.61 & 161.8 & -7.01 & 151.8 & -12.75 \\
\hline 90 & 46332 & 169.8 & 160.9 & -5.26 & 158.9 & -6.45 & 151.0 & -11.07 \\
\hline $\begin{array}{l}\mathrm{N}_{\mathrm{D}} \\
{[\%]}\end{array}$ & $\begin{array}{c}\mathbf{N}_{\mathrm{D}} \\
{[\mathrm{kW}]}\end{array}$ & $\underset{[\%]}{\eta_{\mathrm{D}}}$ & $\begin{array}{c}\eta_{\mathrm{PT}} \\
{[\%]}\end{array}$ & $\begin{array}{c}\Delta \boldsymbol{\eta}_{\mathrm{PT}} / \boldsymbol{\eta}_{\mathrm{D}} \\
{[\% \mathbf{\%}]}\end{array}$ & $\begin{array}{c}\eta_{\mathrm{ST}} \\
{[\%]}\end{array}$ & $\begin{array}{c}\Delta \boldsymbol{\eta}_{\mathrm{ST}} / \boldsymbol{\eta}_{\mathrm{D}} \\
{[\% \mathbf{0}]}\end{array}$ & $\begin{array}{c}\eta_{\text {combi }} \\
{[\%]}\end{array}$ & $\underset{[\%]}{\Delta \boldsymbol{\eta}_{\text {combi }} / \boldsymbol{\eta}_{\mathbf{D}}}$ \\
\hline 100 & 51480 & 48.43 & 51.89 & 7.08 & 52.11 & 7.54 & 55.54 & 14.61 \\
\hline 90 & 46332 & 49.66 & 52.41 & 5.55 & 53.07 & 6.89 & 55.84 & 12.44 \\
\hline
\end{tabular}


Tab. 3. Comparing steam cycle parameters for load equal to $90 \%$ of main engine power

\begin{tabular}{|c|c|c|c|c|c|c|c|c|c|c|}
\hline Combined system & $\begin{array}{c}\mathbf{t}_{\mathbf{o}} \\
{\left[{ }^{\circ} \mathbf{C}\right]}\end{array}$ & $\begin{array}{c}\mathbf{p}_{\mathbf{o}} \\
{[\mathbf{b a r}]}\end{array}$ & $\begin{array}{c}\mathbf{p}_{\mathbf{I}} \\
{[\mathbf{b a r}]}\end{array}$ & $\begin{array}{c}\mathbf{p}_{\mathbf{g}} \\
{[\mathbf{b a r}]}\end{array}$ & $\begin{array}{c}\mathbf{t}_{\text {exh }} \\
{\left[{ }^{\circ} \mathbf{C}\right]}\end{array}$ & $\begin{array}{c}\mathbf{t}_{\mathrm{FW}} \\
{\left[{ }^{\circ} \mathbf{C}\right]}\end{array}$ & $\mathbf{x}$ & $\begin{array}{c}\mathbf{m}_{\mathbf{o}} \\
{[\mathbf{t} / \mathbf{h}]}\end{array}$ & $\begin{array}{c}\mathbf{m}_{\mathbf{I}} \\
{[\mathbf{t} / \mathbf{h}]}\end{array}$ & $\begin{array}{c}\mathbf{m}_{\mathbf{u}} \\
{[\mathbf{t} / \mathbf{h}]}\end{array}$ \\
\hline Steam turbine & 289 & 19 & 7 & 2 & 165 & 121 & 0.88 & 15.02 & 7.15 & 2.86 \\
\hline Power turbine - fed in parallel & 286 & 19 & 7 & 2 & 164 & 121 & 0.88 & 13.59 & 7.87 & 2.86 \\
\hline Power turbine - fed in series & 286 & 23 & 7 & 2 & 164 & 121 & 0.87 & 12.52 & 10.02 & 3.22 \\
\hline
\end{tabular}

Tab. 4. Comparing power outputs for different variants of the combined system - with power output of the standard main engine as the reference

\begin{tabular}{|c|c|c|c|c|c|c|c|}
\hline \multirow{2}{*}{\multicolumn{2}{|c|}{ Main engine power output }} & \multirow{2}{*}{\multicolumn{2}{|c|}{$\begin{array}{l}\text { Main engine - } \\
\text { steam turbine [2] }\end{array}$}} & \multicolumn{4}{|c|}{ Main engine - power turbine - steam turbine } \\
\hline & & & & \multicolumn{2}{|c|}{ Feeding in parallel [3] } & \multicolumn{2}{|c|}{ Feeding in series } \\
\hline \multicolumn{2}{|c|}{$[\%]$} & {$[\mathbf{k W}]$} & {$[\%]$} & {$[\mathbf{k W}]$} & {$[\%]$} & {$[\mathbf{k W}]$} & {$[\%]$} \\
\hline \multirow{2}{*}{$\begin{array}{l}\text { Steam } \\
\text { turbine }\end{array}$} & 100 & 3823 & 7.43 & 3794 & 7.37 & 3880 & 7.54 \\
\hline & 90 & 3182 & 6.87 & 3075 & 6.64 & 3193 & 6.89 \\
\hline \multirow{2}{*}{$\begin{array}{l}\text { Power } \\
\text { turbine }\end{array}$} & 100 & & & 3203 & 6.22 & 3643 & 7.07 \\
\hline & 90 & & & 2211 & 4.77 & 2572 & 5.55 \\
\hline
\end{tabular}

For combined system variants with the power turbine, the largest power is obtained in the variant with the power turbine fed in series, Tab. 4. In this cases the power output is higher by about $16.3 \%$ compared to the power turbine from the variant of parallel turbine feeding with the exhaust gas for $90 \%$ of main engine load.

In the analysed variants the power output of the steam turbine is larger than that of the power turbine by $6.1-28.8 \%$, depending on the system variant and main engine load, Tab. 4.

Depending on the variant and main engine load, the application of the combined ship power transmission system makes it possible to increase the power output of the power plant by $6.9-14.6 \%$ as compared to the conventional power plant, without delivering extra fuel, Tab. 5. The additional power output of the system is obtained by utilisation of the energy in the exhaust gas leaving the piston engine. This way the combined system reduces the specific fuel consumption by $6.4-12.8 \%$ compared to the conventional power plant.

Depending on the adopted solution, the application of the combined power plant makes it possible to reach the assumed power output of the power transmission system at smaller main engine loads, thus reducing the 24-hour fuel consumption of the ship power plant. Tab. 6 presents, for the assumed power output of the ship power plant, the main engine power output and the reduction of the 24-hour fuel consumption, in relation to the conventional power plant, as a function of the adopted variant of the combined power plant.

Tab. 5. Comparing different combined system variants

\begin{tabular}{|c|c|c|c|c|c|c|}
\hline & & \multirow{3}{*}{$\begin{array}{c}\text { Main } \\
\text { engine load }\end{array}$} & \multirow{3}{*}{$\begin{array}{c}\text { Main } \\
\text { engine }\end{array}$} & \multicolumn{3}{|c|}{ Combined power transmission system } \\
\hline & & & & \multirow{2}{*}{$\begin{array}{c}\text { Steam } \\
\text { turbine [2] }\end{array}$} & \multicolumn{2}{|c|}{ Power turbine fed } \\
\hline & & & & & In parallel [3] & In series \\
\hline \multirow{2}{*}{$\begin{array}{c}\text { System power } \\
\text { output }\end{array}$} & \multirow{2}{*}[\mathbf{kW}]{} & $100 \%$ & 51480 & 55303 & 58477 & 59003 \\
\hline & & $90 \%$ & 46332 & 49514 & 51618 & 52097 \\
\hline \multirow{2}{*}{$\Delta \mathbf{N}_{\text {combi }} / \mathbf{N}_{\mathbf{D}}$} & \multirow{2}{*}[\%]{} & $100 \%$ & & 7.43 & 13.59 & 14.61 \\
\hline & & $90 \%$ & & 6.87 & 11.41 & 12.44 \\
\hline \multirow{2}{*}{ be $_{\text {combi }} / b_{\mathrm{D}}$} & \multirow{2}{*}[\mathrm{g}/\mathbf{kWh}]{} & $100 \%$ & 174.0 & 162.0 & 153.2 & 151.8 \\
\hline & & $90 \%$ & 169.8 & 158.9 & 152.4 & 151.0 \\
\hline \multirow{2}{*}{$\Delta \mathbf{b e}_{\text {combi }} / \mathbf{b e}_{\mathrm{D}}$} & \multirow{2}{*}{ [\%] } & $100 \%$ & & -6.91 & -11.97 & -12.75 \\
\hline & & $90 \%$ & & -6.43 & -10.24 & -11.07 \\
\hline \multirow{2}{*}{ Efficiency $\eta_{\text {combi }}$} & \multirow{2}{*}[\%]{} & $100 \%$ & 48.43 & 52.05 & 55.05 & 55.54 \\
\hline & & $90 \%$ & 49.66 & 53.06 & 55.33 & 55.84 \\
\hline \multirow{2}{*}{$\Delta \boldsymbol{\eta}_{\text {combi }} / \boldsymbol{\eta}_{\mathrm{D}}$} & \multirow{2}{*}[\%]{} & $100 \%$ & & 7.43 & 13.59 & 14.61 \\
\hline & & $90 \%$ & & 6.87 & 11.41 & 12.44 \\
\hline
\end{tabular}

Tab. 6. Reduction of 24-hour fuel consumption of the $49500 \mathrm{~kW}$ ship power plant for particular combined system variants

\begin{tabular}{|c|c|c|c|c|c|}
\hline & \multirow{3}{*}{$\begin{array}{c}\text { Conventional power plant } \\
\text { D }\end{array}$} & \multicolumn{3}{|c|}{ Combined system } \\
\hline & & & \multirow{2}{*}{ D \& ST [2] } & \multicolumn{2}{|c|}{ D \& PT \& ST - feeding: } \\
\hline & & & & In parallel [3] & In series \\
\hline \multirow{2}{*}{ Main engine load } & {$[\mathrm{kW}]$} & 49500 & 46319 & 44701 & 44345 \\
\hline & {$[\%]$} & 96 & 90 & 86.8 & 86.1 \\
\hline 24-hour fuel consumption & {$[\mathrm{t} / 24 \mathrm{~h}]$} & 205 & 189 & 181 & 179 \\
\hline \multirow{2}{*}{ Fuel consumption reduction } & {$[\mathrm{t} / 24 \mathrm{~h}]$} & - & 16 & 24 & 25.8 \\
\hline & {$[\%]$} & - & 7.8 & 11.7 & 12.6 \\
\hline
\end{tabular}




\section{FINAL CONCLUSIONS FROM THE ANALYSIS OF COMBINED SHIP POWER TRANSMISSION SYSTEM VARIANTS}

- It results from the analysis of the optimised combined ship power transmission system that the highest efficiency is obtained when particular power transmission system components are used:

- diesel engine with maximum efficiency

- turbocharger. Most highly efficient turbocharger is to be used, to provide opportunities for reducing the exhaust gas pressure at its outlet, and, consequently, increasing the power of the power turbine

- power turbine. High efficiency power turbine is required to increase its power output

- steam turbine cycle. The waste heat boiler is expected to reveal low exhaust gas flow losses (they decrease the expansion end pressure in the power turbine) and small temperature concentration in boiler evaporators (pitch point). Observed is the high impact of sulphur content in the fuel on the permissible temperature of the exhaust gas and the low temperature limit for the supply water. The least possible number of heat exchangers (none, as an ideal case) is to be used in the steam turbine cycle. The optimum parameters of this cycle also depend on the piston engine load.

- The power transmission system of the combined ship power plant of a big transoceanic container ship, consisting of the main Diesel engine, the power turbine and the steam turbine, makes it possible to:

- increase the power plant power output by $6.9 \div 14.6 \%$ compared to the conventional power plant, without delivering extra fuel

- increase the power efficiency of the power plant from $53 \%$ to about $56 \%$ (which, so far, was impossible to reach by the internal combustion engine alone) depending on the applied variant of the combined power plant. Reducing the content of sulphur in the fuel provides opportunities for reaching higher efficiencies resulting from larger power of the steam turbine - lower temperature of the exhaust gas leaving the waste heat boiler

- reduce the specific fuel consumption by $6.4 \div 13 \%$, without delivering extra fuel, as a consequence of the increased power output compared to that of the conventional power plant

- use the internal combustion engine having lower power output, due to the extra power obtained in the combined system, or to reach $100 \%$ of power output of the power plant when the Diesel engine load is at an approximate level of $90 \%$.

- In the article, only thermodynamic analysis of the power plant is presented, without additional technical and economic analyses, which could fully justify the application of this power plant system for driving a large container ship.

\section{NOMENCLATURE}

$b_{e} \quad-$ specific fuel oil consumption

$c_{g}, c_{a}-$ specific heat of exhaust gas and air

- specific enthalpy

m - mass flow rate

$\mathrm{N} \quad-$ power

$\mathrm{p} \quad$ - pressure

$\mathrm{T}, \mathrm{t}$ - temperature

$\mathrm{Wu} \quad$ - caloric value of fuel oil

$\chi \quad$ - steam dryness ratio

$\eta \quad$ - efficiency

$\kappa_{\mathrm{g}}, \kappa_{\mathrm{a}} \quad$ - isentropic exponent of exhaust gas and air

Indices

bar - barometric conditions

B - boiler

combi - combined system

D - marine diesel engine, supercharging

f - fuel

inlet - inlet duct

$\mathrm{k} \quad$ - parameters in a condenser

o - live steam, calculation point

air - air

ss $\quad$ - ship living purposes

$\pi \quad$ - compression ratio in a compressor, expansion ratio in a turbine

- compressor

- exhaust gas

- turbine

- turbocharger

- power turbine

- steam turbine

- outlet duct

FW - water supplying a waste-heat boiler

\section{BIBLIOGRAPHY}

1. A new turbocharger generation. ABB Turbo Systems Ltd. Publication No. CH-Z 2035 98E.

2. Dzida M.: On the possible increasing of efficiency of ship power plant with the system combined of a marine diesel engine, gas turbine and steam turbine, at the main engine-steam turbine mode of cooperation. PMR No 1(59), Vol. 16, 2009

3. Dzida M., Mucharski J.: Possible ways of increasing the efficiency of the ship power plant with the piston internal combustion engine - gas turbine - steam turbine system in case of main engine cooperation with the gas turbine fed in parallel and the steam turbine. PMR No 2(60), Vol. 16, 2009

4. Schrott K. H.: The New Generation of MAN B\&W Turbochargers. MAN B\&W Publication S.A. 236 5581E. 1995

5. Sulzer RTA 96C. Engine Selection and Project Manual. June 2001. Wärtsilä.

\section{CONTACT WITH THE AUTHORS}

Marek Dzida, Assoc. Prof. Faculty of Ocean Engineering and Ship Technology

Gdansk University of Technology

Narutowicza 11/12

80-233 Gdansk, POLAND

e-mail: dzida@pg.gda.pl 